\title{
Effect of soil coarseness on soil base cations and available micronutrients in a semi-arid sandy grassland
}

\author{
Linyou Lï̈ ${ }^{1,2}$, Ruzhen Wang ${ }^{1}$, Heyong Liu ${ }^{1,3}$, Jinfei Yin ${ }^{1,4}$, Jiangtao Xiao ${ }^{1,4}$, Zhengwen Wang ${ }^{1}$, Yan Zhao ${ }^{2}$, \\ Guoqing Yu ${ }^{2}$, Xingguo Han ${ }^{1}$, and Yong Jiang ${ }^{1}$ \\ ${ }^{1}$ State Key Laboratory of Forest and Soil Ecology, Institute of Applied Ecology, Chinese Academy of Sciences, \\ Shenyang 110016, China \\ ${ }^{2}$ Institute of Sandyland Improvement and Utilization, Liaoning Academy of Agricultural Sciences, Fuxin 123000, China \\ ${ }^{3}$ Key Laboratory of Regional Environment and Eco-remediation, College of Environment, Shenyang University, \\ Shenyang 110044, China \\ ${ }^{4}$ University of Chinese Academy of Sciences, Beijing 10049, China \\ Correspondence to: Ruzhen Wang (ruzhenwang@iae.ac.cn)
}

Received: 26 January 2016 - Published in Solid Earth Discuss.: 27 January 2016

Revised: 14 March 2016 - Accepted: 3 April 2016 - Published: 12 April 2016

\begin{abstract}
Soil coarseness is the main process decreasing soil organic matter and threatening the productivity of sandy grasslands. Previous studies demonstrated negative effect of soil coarseness on soil carbon storage, but less is known about how soil base cations (exchangeable $\mathrm{Ca}, \mathrm{Mg}, \mathrm{K}$, and $\mathrm{Na}$ ) and available micronutrients (available $\mathrm{Fe}, \mathrm{Mn}, \mathrm{Cu}$, and $\mathrm{Zn}$ ) response to soil coarseness. In a semi-arid grassland of Northern China, a field experiment was initiated in 2011 to mimic the effect of soil coarseness on soil base cations and available micronutrients by mixing soil with different mass proportions of sand: $0 \%$ coarse elements (C0), $10 \%$ (C10), 30\% (C30), $50 \%$ (C50), and $70 \%$ (C70). Soil coarseness significantly increased soil $\mathrm{pH}$ in three soil depths of $0-10,10-20$ and $20-40 \mathrm{~cm}$ with the highest $\mathrm{pH}$ values detected in C50 and C70 treatments. Soil fine particles (smaller than $0.25 \mathrm{~mm}$ ) significantly decreased with the degree of soil coarseness. Exchangeable $\mathrm{Ca}$ and $\mathrm{Mg}$ concentrations significantly decreased with soil coarseness degree by up to $29.8 \%$ (in C70) and $47.5 \%$ (in C70), respectively, across three soil depths. Soil available $\mathrm{Fe}, \mathrm{Mn}$, and $\mathrm{Cu}$ significantly decreased with soil coarseness degree by $62.5,45.4$, and $44.4 \%$, respectively. As affected by soil coarseness, the increase of soil $\mathrm{pH}$, decrease of soil fine particles (including clay), and decline in soil organic matter were the main driving factors for the decrease of exchangeable base cations (except K) and available micronutrients (except $\mathrm{Zn}$ ) through soil profile. Developed under soil coarseness, the loss and redistribution of
\end{abstract}

base cations and available micronutrients along soil depths might pose a threat to ecosystem productivity of this sandy grassland.

\section{Introduction}

Dryland ecosystems, accounting for $41 \%$ of the total land area of the world, are prone to desertification which would result in soil coarseness (Cerdà et al., 2014; T. Wang et al., 2015). Dryland ecosystems represent $25 \%$ of land surface area in Latin America, with $75 \%$ of them having desertification problems (Torres et al., 2015). Desertified land area has been reported to reach 45.6 million $\mathrm{km}^{2}$ (Torres et al., 2015) and account for $74 \%$ of total dryland area $\left(61.5\right.$ million $\left.\mathrm{km}^{2}\right)$, with more than 100 countries and $8.5 \times 10^{8}$ people being affected (Miao et al., 2015; Vieira et al., 2015; T. Wang et al., 2015). Desertification exerts a large impact on social and economic resources (Beyene, 2015; Escadafal et al., 2015). Areas susceptible to desertification tend to be marked by socioeconomic inequality and have a low human development index in Brazil (Vieira et al., 2015). Desertification was reported to cause economic losses of up to EUR 6 billion in Northern China in the year 2005 (Miao et al., 2015).

In China, most of the grasslands have undergone degradation and desertification with $50 \%$ distributed in the agro- 
pastoral transition zone of Northern China (T. Wang et al., 2015; Yan and Cai, 2015). Continuous grazing and intense cultivation can reduce vegetation cover and litter accumulation, which exposes the ground surface to wind erosion in the erosion-prone sandy lands (Su et al., 2005). Desertification and wind erosion processes in fragile arid and semiarid rangelands have contributed to increased soil coarseness (Yan and Cai, 2015). Together with reduction of plant cover, increased soil coarseness contributes to a loss of agricultural productivity, environmental deterioration, and associated social and economic disruptions (Vieira et al., 2015; Xie et al., 2015). In this case, it is urgent to combat desertification and study the causes, processes, consequences, and mechanisms of soil coarseness (Xu et al., 2012; Weinzierl et al., 2016).

Soil base cations are not only essential nutrient cations for both plants and soil microbes but also serve as one of the main mechanisms of soil acid buffering capacity (Lu et al., 2014) and are a good indicator of soil fertility (Zhang et al., 2013). Micronutrient availabilities essentially affect terrestrial net primary production, plant quality, and consequently food and forage supply worldwide (Cheng et al., 2010; Marques et al., 2015). Current research about desertification and soil coarseness mainly focuses on their effects on degradation of forest and grasslands due to logging and overgrazing (Conte et al., 1999; Cao et al., 2008), C and $\mathrm{N}$ depletion in soils and plant components (Zhou et al., 2008; Bisaro et al., 2014), soil compaction and erosion risk (Allington and Valone, 2010), and soil physical properties of particle size distributions (Su et al., 2004; Huang et al., 2007). However, less is known about the changes in soil base cations and availabilities of micronutrient during dryland desertification and soil coarseness.

Soil coarseness is suggested to cause a decrease of soil silt and clay contents (Zhou et al., 2008), decrease of soil C and nutrient (such as N and P) concentrations (Xie et al., 2015), and losses in species diversity and productivity (Zhao et al., 2006; Huang et al., 2007). As biogeochemical cyclings of base cations and micronutrients are largely controlled by soil organic matter (SOM) (complexation and chelation; Sharma et al., 2004) and properties of soil mineral (reversible sorption and desorption processes; Jobbágy and Jackson, 2004), decrease of SOM and soil fine particles would potentially decrease soil base cations and micronutrient availability. Also, the changes in SOM along soil depth could shape the vertical distribution of base cations and available micronutrients (Sharma et al., 2004).

The Horqin Sandy Land, or Horqin sandy grassland, is an important part of Inner Mongolian grassland and one of the main sandy areas in Northern China, covering approximately $43000 \mathrm{~km}^{2}$ (Li et al., 2004). With windy and dry winters and springs in Horqin region, the soils are prone to aeolian soil erosion and soil coarseness, especially when natural sandy grassland is converted into farmland ( $\mathrm{Li}$ et al., 2004). To examine the effect of soil coarseness during desertification on the concentrations of soil base cations (exchangeable

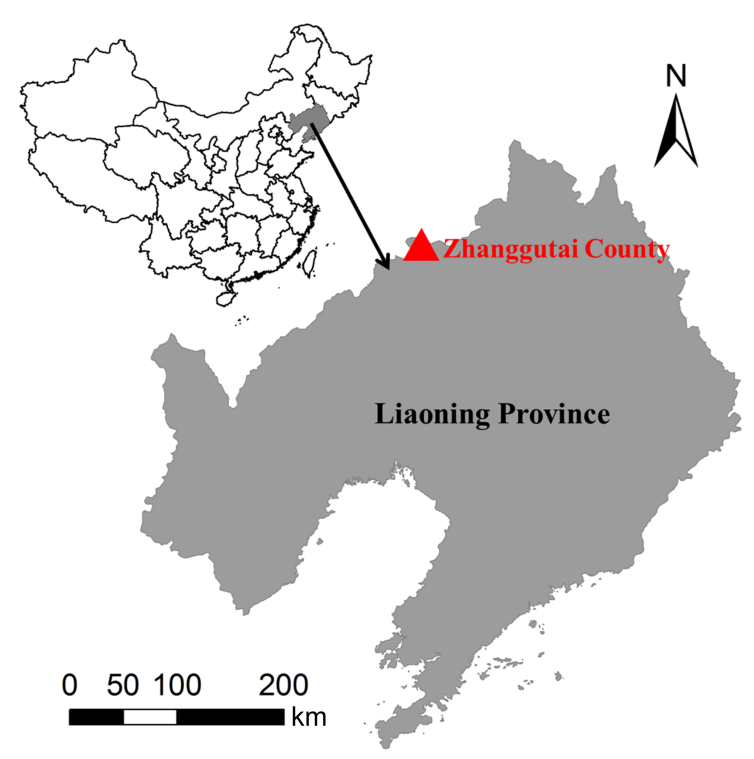

Figure 1. Location of the experimental site.

$\mathrm{Ca}, \mathrm{Mg}, \mathrm{K}$, and $\mathrm{Na}$ ) and available micronutrients $(\mathrm{Fe}, \mathrm{Mn}$, $\mathrm{Cu}$, and $\mathrm{Zn}$ ) of this region, we set up a field experiment in Zhanggutai by mixing the soil with different mass proportions of sand: $10 \%$ (light soil coarseness), $30 \%$ (moderate soil coarseness), $50 \%$ (heavy soil coarseness), and $70 \%$ (severe soil coarseness). We hypothesized that both soil base cations and available micronutrients would decrease with the increasing degree of soil coarseness due to the decrease of SOM and soil fine particles. We also expected that soil base cations and available micronutrients would decrease with soil depth.

\section{Materials and methods}

\subsection{Study area}

The study was conducted at the Desertified Grassland Restoration Research Station maintained by the Institute of Sand Fixation and Utilization, Liaoning Academy of Agricultural Sciences. The study site $\left(42^{\circ} 43^{\prime} \mathrm{N}\right.$ and $122^{\circ} 22^{\prime} \mathrm{E}$, elevation $226.5 \mathrm{~m}$ a.s.1.) was located in the southeast of Horqin Sandy Land, near Zhanggutai Town, Zhangwu County, Liaoning Province, China (Fig. 1). Productive grasslands from Zhanggutai County have undergone severe desertification due to intense cultivation, overgrazing, and increased population ( $\mathrm{Li}$ et al., 2000; Chen et al., 2005). The soils are susceptible to wind erosion as a result of a decrease in plant cover and high annual wind velocity (varies from 3.4 to $4.1 \mathrm{~m} \mathrm{~s}^{-1}$ ) with frequent occurrence of gales (wind speed $>20 \mathrm{~m} \mathrm{~s}^{-1}$; Li et al., 2000). The mean annual temperature is $6.2^{\circ} \mathrm{C}$ and mean annual precipitation is about $450 \mathrm{~mm}$, which defines the area as semi-arid (Chen et al., 2005). The frost-free period lasts approximately 150 days 
(Chen et al., 2005). Soil texture of the experiment site is sandy soil with $99.32 \pm 0.13 \%$ sand, $0.45 \pm 0.14 \%$ silt, and $0.23 \pm 0.02 \%$ clay (means \pm standard deviation; data measured from control soil). The soil type is classified as a Aeolic Eutric Arenosol according to the FAO classification (IUSS Working Group WRB, 2014). Arenosols are mainly developed in sand dune areas which feature a sandy texture and low soil organic carbon (SOC) concentrations and are prone to soil coarsening (Barthold et al., 2013). This area constitutes an agro-pastoral ecotone which is severely degraded due to excessive cultivation and grazing (Chen et al., 2005).

\subsection{Experimental design}

In May 2011, a complete randomized design was applied to the site. Within a $24 \mathrm{~m} \times 29 \mathrm{~m}$ area $\left(696 \mathrm{~m}^{2}\right), 304 \mathrm{~m} \times 4 \mathrm{~m}$ plots were established for five treatments with six replicates per treatment. The soil within this experimental area is homogenous. Adjacent plots were separated by $1 \mathrm{~m}$ buffer zone and PVC plates to prevent water and nutrient exchanges. A certain mass proportion of $2 \mathrm{~mm}$ sieved river sand (siliceous, $\mathrm{pH} 7.5 \pm 0.2)$ was mixed with native soil for each of three depths (0-20, 20-40, and 40-60 cm). Three soil depths were considered in this study to study effect of soil coarseness on soil properties of plant root layer $(0-20 \mathrm{~cm})$, transition layer of plant roots $(20-40 \mathrm{~cm})$, and transition layer of soil genesis $(40-60 \mathrm{~cm})$. To mix the river sand and native soils evenly in each plot, soils of each depth were dug out and mixed with the sand by agitators in the same mass proportion separately. The soils were refilled back to the field in respective depths after mixture. The proportions are $0,10,30,50$, and $70 \%$ to mimic different soil coarseness degrees or intensities: control grassland without soil coarseness (C0), light soil coarseness (C10), moderate soil coarseness (C30), heavy soil coarseness (C50), and severe soil coarseness (C70), respectively. In August $2012,0-5 \mathrm{~cm}$ soils of all plots were taken out and autoclaved at $105^{\circ} \mathrm{C}$ for $3 \mathrm{~h}$ to deactivate the seeds and then refilled. This was adequate to prevent the reproduction of original plants. In July 2013, plant community was transplanted from local natural grassland according to its species composition by point quadrats (Goodall, 1952). At the start of this experiment, the plant community composition was the same for all the treatment plots. Plant community composition was investigated in a permanent quadrat of $1 \mathrm{~m} \times 1 \mathrm{~m}$ in August of 2014 and 2015 (unpublished data). The plant community at the site is dominated by Carex duriuscula. The chemical characteristics of the $0-10 \mathrm{~cm}$ soil are given in Table 1 .

\subsection{Soil sampling and chemical analysis}

In October 2015 (i.e., after 2 years of plant community settled), a composite soil sample was taken from three randomly selected locations within each plot from three soil layers of 0-10, 10-20, and 20-40 cm. Fresh soil samples were sieved through $2 \mathrm{~mm}$ screen and visible plant roots were taken out.
Table 1. Mean and range of soil chemical characteristics for 0 $10 \mathrm{~cm}$ soil in different soil coarseness degrees from $0 \%$ sand addition $(\mathrm{C} 0)$ to $70 \%(\mathrm{C} 70)$.

\begin{tabular}{ll}
\hline & $\begin{array}{l}\text { Range of mean } \\
\text { from C0 to C70 }\end{array}$ \\
\hline Soil organic carbon $\left(\mathrm{g} \mathrm{kg} \mathrm{soil}^{-1}\right)$ & $4.1-2.7$ \\
Total nitrogen $\left(\mathrm{g} \mathrm{kg} \mathrm{soil}^{-1}\right)$ & $0.48-0.22$ \\
Dissolved organic carbon $\left(\mathrm{mg} \mathrm{kg} \mathrm{soil}^{-1}\right)$ & $66.3-53.9$ \\
Microbial biomass C $\left(\mathrm{mg} \mathrm{kg} \mathrm{soil}^{-1}\right)$ & $104.3-60.4$ \\
Electric conductivity $\left(\mu \mathrm{sm}^{-1}\right)$ & $54.7-44.7$ \\
\hline
\end{tabular}

After transportation to laboratory, the soils were air-dried and a subsample of the soil was ground for $\mathrm{C}$ and $\mathrm{N}$ analysis.

\subsubsection{Soil $\mathrm{pH}$ and particle size distribution}

Soil $\mathrm{pH}$ was determined in a $1: 2.5(w / v)$ soil-to-water extract of soil samples from all treatments with a PHS-3G digital pH meter (Precision and Scientific Corp., Shanghai, China). Soil particle size distribution was determined by the pipette method in a sedimentation cylinder, using Na-hexametaphosphate as the dispersing agent (Zhao et al., 2006). Proportion of soil fine particles $(<0.25 \mathrm{~mm})$ were calculated by summing up the proportions of fine sand, silt, and clay in this study.

\subsubsection{Soil base cations ( $\mathrm{Ca}, \mathrm{Mg}, \mathrm{K}, \mathrm{Na}$ ) and available micronutrients ( $\mathrm{Fe}, \mathrm{Mn}, \mathrm{Cu}, \mathrm{Zn}$ )}

Soil base cations were determined using the $\mathrm{CH}_{3} \mathrm{COONH}_{4}$ extraction method according to Ochoa-Hueso et al. (2014). Briefly, $2.5 \mathrm{~g}$ of soil sample was extracted with $1 \mathrm{M} \mathrm{CH}_{3} \mathrm{COONH}_{4}(\mathrm{pH} 7.0)$ with a soil : extractant ratio of $1: 20(w / v)$ and shaken at $150 \mathrm{rpm}$ for $30 \mathrm{~min}$. After filtration with Whatman no. $2 \mathrm{~V}$ filter paper, the concentrations of soil base cations were determined by atomic absorption spectrometer (AAS, Shimazu, Japan).

Available $\mathrm{Fe}, \mathrm{Mn}, \mathrm{Cu}$, and $\mathrm{Zn}$ were extracted by diethylenetriaminepentaacetic acid (DTPA) according to the method of Lindsay and Norvell (1978). Briefly, $10 \mathrm{~g}$ of soil samples was mixed with $20 \mathrm{~mL}$ $0.005 \mathrm{MDTPA}+0.01 \mathrm{M} \mathrm{CaCl}_{2}+0.1 \mathrm{M}$ triethanolamine (TEA; pH 7.0). The slurry was shaken at $180 \mathrm{rpm}$ for $2 \mathrm{~h}$ and filtered through Whatman no. $2 \mathrm{~V}$ filter paper. The concentrations of available micronutrients were analyzed by AAS.

\subsection{Statistical analyses}

The normality of data was tested using the KolmogorovSmirnov test, and homogeneity of variances using Leven's test. Effects of soil coarseness on soil pH, fine particles, base cations, and available micronutrients were determined 

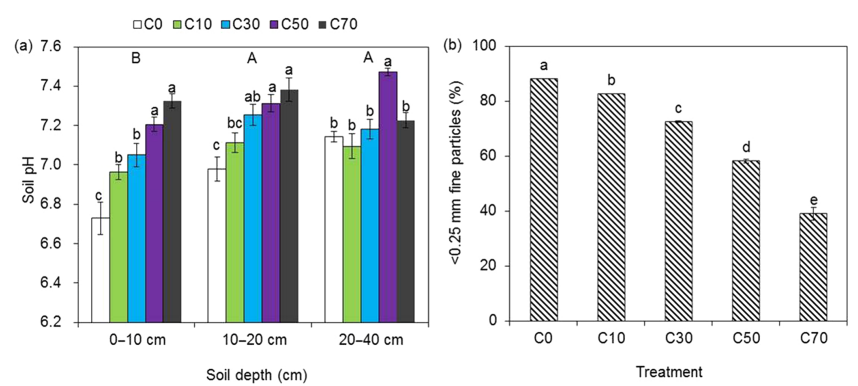

Figure 2. Soil $\mathrm{pH}$ values for three soil depths (a) and proportion of soil fine particles $(<0.25 \mathrm{~mm})$ for $0-10 \mathrm{~cm}$ soil in different soil coarseness degrees of $0 \%$ sand addition (C0), $10 \%$ (C10), $30 \%$ (C30), $50 \%$ (C50), and $70 \%$ (C70). Data represent mean \pm SE $(n=6)$. Letters indicate significant differences among treatments (lowercase letters) and differences among soil depths when averaging across all treatments (capital letters).

by one-way ANOVA. Multiple comparisons with Duncan design were performed to determined difference in soil parameters among soil coarseness degrees. Pearson correlation analysis was used to examine the relationship among soil parameters. Multivariate linear regression analyses (stepwise removal) were conducted to determine variables that made significant contributions to variance of soil base cations and available micronutrients. All statistical analyses were performed in SPSS 16.0 (SPSS, Inc., Chicago, IL, USA) and statistical significance was accepted at $P<0.05$.

\section{Results}

\subsection{Soil pH}

Soil coarseness significantly increased soil $\mathrm{pH}$ by up to $8.8 \%$ across three soil depths (Fig. 2a; Table 2). For both $0-10$ and $10-20 \mathrm{~cm}$ soils, the highest soil $\mathrm{pH}$ was detected in $\mathrm{C} 70$ (7.3 and 7.4, respectively) and C50 (7.2 and 7.3, respectively) soils, which were followed by $\mathrm{C} 30$ and $\mathrm{C} 10$ soils (Fig. 2a). Significant and positive overall effect of soil depth was detected on soil pH (Fig. 2a; Table 2). For both $\mathrm{C} 0$ and $\mathrm{C} 50$ treatments, soil $\mathrm{pH}$ of $10-20$ and $20-40 \mathrm{~cm}$ was significantly higher as compared to that of $0-10 \mathrm{~cm}$ soil (Fig. 2a). Soil pH in $10-20 \mathrm{~cm}$ of $\mathrm{C} 10$ and $\mathrm{C} 30$ was significantly higher than that in $0-10 \mathrm{~cm}$ of C10 and C30, respectively (Fig. 2a). Significant interactive effect of soil coarseness and soil depth was found on soil $\mathrm{pH}$ (Table 2).

Proportions of soil fine particles $(<0.25 \mathrm{~mm})$ were determined in $0-10 \mathrm{~cm}$ soil. Soil fine particles significantly decreased with soil coarseness degree by $6.3 \%$ (for treatment of $\mathrm{C} 10), 17.7 \%$ (C30), $34.1 \%$ (C50), and $55.6 \%$ (C70) as compared to $\mathrm{C} 0$ (Fig. 2b). The lowest proportion of soil fine particles was detected in C70 (39.1\%), followed by C50 (58.1\%; Fig. 2b). The proportion of clay particles significantly decreased under soil coarseness (Fig. S1).

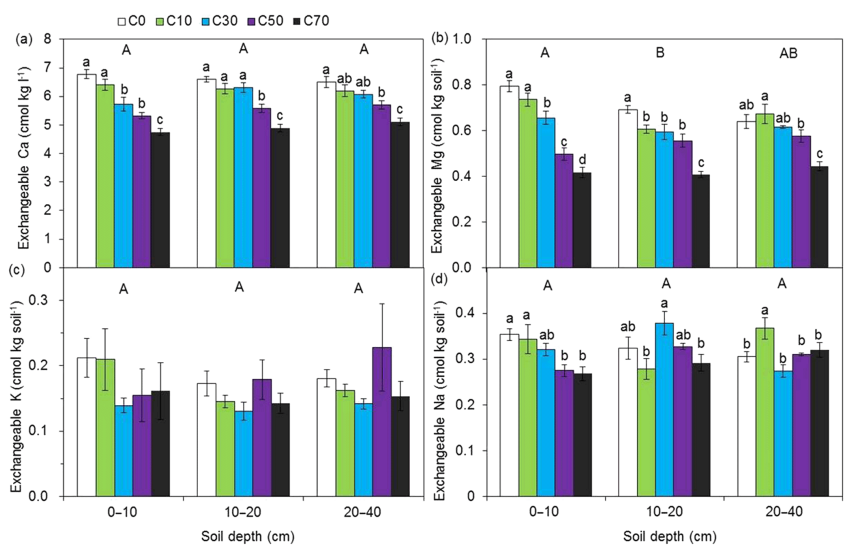

Figure 3. Soil base cations of exchangeable $\mathrm{Ca}$ (a), $\mathrm{Mg}$ (b), $\mathrm{K}$ (c), and $\mathrm{Na}(\mathbf{d})$ for three soil depths in different soil coarseness degrees of $0 \%$ sand addition (C0), $10 \%$ (C10), $30 \%$ (C30), $50 \%$ (C50), and $70 \%(C 70)$. Data represent mean $\pm \operatorname{SE}(n=6)$. Letters indicate significant differences among treatments (lowercase letters) and differences among soil depths when averaging across all treatments (capital letters). Bars without letters above denote no significance is detected among treatments.

\subsection{Soil base cations}

Across three soil depths, soil coarseness significantly decreased both exchangeable $\mathrm{Ca}$ and $\mathrm{Mg}$ concentrations by up to 29.8 and $47.5 \%$, respectively, as compared to C0 (Fig. 3a, b). Both exchangeable $\mathrm{Ca}$ and $\mathrm{Mg}$ concentrations were the lowest in the C70 and followed by C50 as compared to $\mathrm{C} 0$ in all soil depths (Fig. 3a, b). Soil depth significantly decreased soil-exchangeable $\mathrm{Mg}$, while showed no effect on exchangeable $\mathrm{Ca}$ (Table 2). Both soil coarseness and soil depth had no impact on soil-exchangeable $\mathrm{K}$ (Fig. 3c). At $0-10 \mathrm{~cm}, \mathrm{C} 50$ and C70 significantly decreased soil-exchangeable $\mathrm{Na}$ by 22.3 and $24.2 \%$, respectively, as compared to $\mathrm{C} 0$ (Fig. 3d). Soil-exchangeable Na did not change with soil depth (Fig. 3d, Table 2).

\subsection{Soil available micronutrients}

Soil available Fe significantly decreased with soil coarseness degree by as much as $17.1 \%$ in C10, $22.0 \%$ in C30, 36.6\% in C50, and $62.5 \%$ in C70 across three soil depths (Fig. 4a). Soil coarseness significantly decreased Soil available Mn for $0-10 \mathrm{~cm}$ (by up to $17.3 \%$ in C70) and $10-20 \mathrm{~cm}$ (by up to $45.4 \%$ in C70) soils (Fig. 4b). Both Soil available Fe and Mn significantly decreased with soil depth (Fig. 4a, b; Table 2). Significant negative soil coarseness effect was detected on Soil available $\mathrm{Cu}$ by $14.7-44.4 \%$ as compared to $\mathrm{C} 0$ in 0 $10 \mathrm{~cm}$ soil (Fig. 4c). For both C30 and C50 treatments, Soil available $\mathrm{Cu}$ concentration of $10-20 \mathrm{~cm}$ soil was significantly higher than that in $0-10$ and $20-40 \mathrm{~cm}$ soils. Soil available $\mathrm{Zn}$ concentration was not affected by soil coarseness but it decreased with soil depth (Fig. 4d; Table 2). 
Table 2. Results ( $F$ values) of two-way ANOVAs on the effect of soil depth $(D)$, treatments of soil coarseness degrees $(T)$, and their interactions on soil base cations (exchangeable $\mathrm{Ca}, \mathrm{Mg}, \mathrm{K}$, and $\mathrm{Na}$ ) and available micronutrients ( $\mathrm{Fe}, \mathrm{Mn}, \mathrm{Cu}, \mathrm{and} \mathrm{Zn}$ ).

\begin{tabular}{lrrrrrrrrr}
\hline & $\mathrm{pH}$ & $\mathrm{Ca}$ & $\mathrm{Mg}$ & $\mathrm{K}$ & $\mathrm{Na}$ & $\mathrm{Fe}$ & $\mathrm{Mn}$ & $\mathrm{Cu}$ & $\mathrm{Zn}$ \\
\hline$D$ & $17.33^{* *}$ & 0.99 & $4.54^{*}$ & 0.74 & 0.22 & $135.67^{* *}$ & $99.63^{* *}$ & $9.69^{* *}$ & $22.13^{* *}$ \\
$T$ & $31.74^{* *}$ & $50.26^{* *}$ & $57.22^{* *}$ & 1.61 & 2.35 & $41.51^{* *}$ & $12.11^{* *}$ & $10.60^{* *}$ & 0.62 \\
$D \times T$ & $4.12^{* *}$ & 1.49 & $3.81^{* *}$ & 0.64 & $5.02^{* *}$ & $2.97^{* *}$ & $2.49^{*}$ & $3.40^{* *}$ & 0.83
\end{tabular}

* Significance level at $P<0.05$. ${ }^{* *}$ Significance level at $P<0.01$.

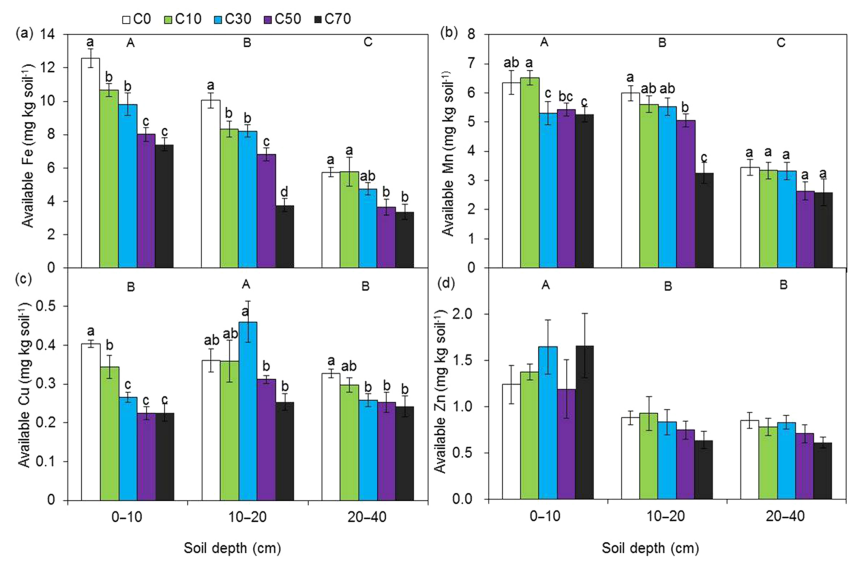

Figure 4. Soil available micronutrients of available Fe (a), Mn (b), $\mathrm{Cu}(\mathbf{c})$, and $\mathrm{Zn}$ (d) for three soil depths in different soil coarseness degrees of $0 \%$ sand addition (C0), $10 \%$ (C10), 30\% (C30), $50 \%$ (C50), and $70 \%$ (C70). Data represent mean \pm SE $(n=6)$. Letters indicate significant differences among treatments (lowercase letters) and differences among soil depths when averaging across all treatments (capital letters). Bars without letters above denote no significance is detected among treatments.

\subsection{Regression analyses between soil parameters}

All regression analysis were conducted for $0-10 \mathrm{~cm}$ soil as the data of fine particles $(<0.25 \mathrm{~mm})$ were only available for $0-10 \mathrm{~cm}$ soil. At $0-10 \mathrm{~cm}$ soil, soil $\mathrm{pH}$ significantly and negatively correlated with exchangeable $\mathrm{Ca}, \mathrm{Mg}$, and $\mathrm{Na}$ and with available $\mathrm{Fe}, \mathrm{Mn}$, and $\mathrm{Cu}$ (Table 3). Soil fine particles $(<0.25 \mathrm{~mm})$ significantly and positively correlated with exchangeable $\mathrm{Ca}$, exchangeable $\mathrm{Mg}$, exchangeable $\mathrm{Na}$, available $\mathrm{Fe}$, available $\mathrm{Mn}$, and available $\mathrm{Cu}$ (Table 3). The SOC significantly and positively correlated with exchangeable $\mathrm{Ca}$, $\mathrm{Mg}$, Na, available $\mathrm{Fe}, \mathrm{Mn}$, and $\mathrm{Cu}$ (Table 3).

According to multiple regression models, change of soil fine particles explained $65.5,75.7,31.4$, and $24.0 \%$ of variations in exchangeable $\mathrm{Ca}, \mathrm{Mg}, \mathrm{Na}$, and available $\mathrm{Mn}(\mathrm{Ta}-$ ble 3). Soil $\mathrm{pH}$ explained $75.7 \%$ of variation in available $\mathrm{Fe}$ (Table 2). The SOC explained $59.3 \%$ of variation in available $\mathrm{Cu}$ (Table 2).
Table 3. Regression statistics relating soil base cations (exchangeable $\mathrm{Ca}, \mathrm{Mg}, \mathrm{K}$, and $\mathrm{Na}$ ) and available micronutrients $(\mathrm{Fe}, \mathrm{Mn}, \mathrm{Cu}$, and $\mathrm{Zn}$ ) to soil $\mathrm{pH}$, soil fine particles $(<0.25 \mathrm{~mm})$, and soil organic carbon (SOC).

\begin{tabular}{lrrrr}
\hline & Soil pH & $<0.25 \mathrm{~mm}$ & SOC & Multiple \\
\hline $\mathrm{Ca}$ & -0.67 & $0.81^{*}$ & 0.73 & 0.81 \\
$\mathrm{Mg}$ & -0.75 & $0.87^{*}$ & 0.72 & 0.87 \\
$\mathrm{~K}$ & - & - & - & - \\
$\mathrm{Na}$ & -0.54 & $0.56^{*}$ & 0.56 & 0.56 \\
$\mathrm{Fe}$ & $-0.87^{*}$ & 0.80 & 0.74 & 0.87 \\
$\mathrm{Mn}$ & -0.42 & $0.49^{*}$ & 0.45 & 0.49 \\
$\mathrm{Cu}$ & -0.68 & 0.72 & $0.77^{*}$ & 0.77 \\
$\mathrm{Zn}$ & - & - & - & - \\
\hline
\end{tabular}

Values are $R$ statistics for significant $(P<0.05)$ linear regressions. Multiple is $R$ values for multiple regressions (stepwise removal) of soil base cation and micronutrients with soil pH, $<0.25 \mathrm{~mm}$ fine particles, and SOC. * Indicates variables that make significant contributions to the multiple linear regressions.

\section{Discussion}

\subsection{Effect of soil coarseness on soil base cations and available micronutrients}

Significant decrease in exchangeable $\mathrm{Ca}$ and $\mathrm{Mg}$ concentrations in three soil depths and exchangeable $\mathrm{Na}$ in $0-10 \mathrm{~cm}$ soil as affected by soil coarseness partially supported our first hypothesis. The decrease of exchangeable $\mathrm{Ca}, \mathrm{Mg}$, and $\mathrm{Na}$ might be due to increase of soil $\mathrm{pH}$ under soil coarseness as suggested by the significant and negative correlation between soil $\mathrm{pH}$ and exchangeable $\mathrm{Ca}, \mathrm{Mg}$, and $\mathrm{Na}$ (Table 3). Indeed, with the increase of soil $\mathrm{pH}$, soil base cations (such as $\mathrm{Ca}^{2+}$ and $\left.\mathrm{Mg}^{2+}\right)$ and available micronutrients $\left(\mathrm{Fe}^{2+}, \mathrm{Mn}^{2+}\right.$, and $\mathrm{Cu}^{2+}$ ) would precipitate with $\mathrm{OH}^{-}$(McLean, 1982), resulting in the decrease of soil base cations and available micronutrients under soil coarseness.

Soil fine particles $(<0.25 \mathrm{~mm})$, especially clay inside these fine particles, were suggested to provide additional binding surfaces for exchangeable base cations and available micronutrients (Beldin et al., 2007). Confirmed by the positive correlations of soil fine particles with both base cations (exchangeable $\mathrm{Ca}, \mathrm{Mg}$, and $\mathrm{Na}$ ) and available micronutrients $(\mathrm{Fe}, \mathrm{Mn}$, and $\mathrm{Cu})$, the decrease of soil fine particles and clay content (Fig. S1) might also contribute to lower base cations 
and available micronutrients under soil coarseness. Consistent with our findings, previous studies also suggested that the decrease of soil fine particles and increase of soil coarseness resulted in a loss of SOM as well as a reduction in the nutrient storage (Lopez, 1998; Zhao et al., 2006; Zhou et al., 2008).

As the essential role of SOM in retaining base cations and micronutrients by its functional groups (Oorts et al., 2003), significantly lower soil base cations and micronutrients would possibly be due to lower C (the largest component of SOM) concentration in coarsen soils. This can be further enhanced by the significant positive correlation of soil C with both base cations and micronutrients (Table 3). Consistently, Vittori Antisari et al. (2013) reported that humified organic compounds in soil could retain base cations and decrease their leaching from soils. As compared to higher soil coarseness degree, higher soil microbial activities (unpublished data) under conditions of lower soil coarseness degree could promote humification or microbial processing of the SOM (R. Wang et al., 2015), potentially increasing the availability of functional groups to complex with the base cations and micronutrients. Additionally, higher net primary production and plant nutrient demands would induce the activation of base cation and micronutrients from the soils under lower soil coarseness degree (Burke et al., 1999). Due to the fact of reduction in ecosystem productivity under cation deficiencies (Lawrence et al., 1995; Cheng et al., 2010), the loss of base cations and available micronutrients as developed under soil coarseness could constrain both plant growth and pasture productivity of this nutrient-poor sandy ecosystem.

\subsection{Effect of soil depth on base cations and available micronutrients}

The hypothesized decrease of exchangeable base cations and available micronutrients with soil depth was partially supported as only exchangeable $\mathrm{Mg}$ (Fig. $3 \mathrm{~b}$ ) and available $\mathrm{Fe}$ (Fig. 4a), Mn (Fig. 4b), and Zn (Fig. 4d) decreased with soil depth. Vertical distribution of soil nutrients can be influenced by two opposite processes: leaching and biological cycling (such as plant absorption; Truggill, 1988). Being a ubiquitous process in ecosystems, plant absorption of nutrients can transport soil elements aboveground and return the litterfall to soil surface (Stark, 1994). Especially in this sandy land or desertified grassland, plants tend to accumulate SOM or nutrients to form "island of fertility" (Cao et al., 2008). In these sandy soils, leaching is also an essential process in shaping the vertical distribution of soil nutrients (Truggill, 1988). As leaching moves nutrients downward while biological cycling moves them upward (Jobbágy and Jackson, 2001), the unchanged $\mathrm{Ca}, \mathrm{K}$, and $\mathrm{Na}$ concentrations might be the combining effects of leaching and biological cycling. This area experiences freeze-thaw cycles for at least 4-5 months per year (Alamusa et al., 2014). Freeze-thaw cycles might promote the leaching of exchangeable $\mathrm{Ca}, \mathrm{K}$, and
$\mathrm{Na}$ from surface to subsoil, resulting in the unchanged base cations along soil profile. Our results are in contrast with previous studies, suggesting that ecosystem were more capable to retain K than other base cations (Nowak et al., 1991; Jobbágy and Jackson, 2001). In this case, it is obvious that many environmental factors, like soil types and plant community composition, can be drivers for the vertical distribution of base cations and micronutrients (Burke et al., 1999; Van der Ploeg et al., 2012). The leaching of base cations to subsoils might enhance mineral weathering process and pedogenesis by forming kaolinite in topsoils as rapid removing of watersoluble elements (such as exchangeable $\mathrm{Ca}$ and $\mathrm{Na}$; Chadwick and Chorover, 2001). Stronger effect of plant absorption than leaching might contribute to the shallower distribution of exchangeable $\mathrm{Mg}$ (Fig. 3b) and available Fe (Fig. 4a), Mn (Fig. 4b), and Zn (Fig. 4d). The dominant role of plant cycling in determining the vertical distribution of $\mathrm{Mg}, \mathrm{Fe}$, $\mathrm{Mn}$, and $\mathrm{Zn}$ might illustrate that these elements were scarcer and more limiting nutrients for plant growth in this semi-arid sandy ecosystem (Jobbágy and Jackson, 2001).

\section{Conclusions}

The results showed that grassland soil coarseness decreased soil base cations of exchangeable $\mathrm{Ca}, \mathrm{Mg}$, and $\mathrm{Na}$ as well as available micronutrients of $\mathrm{Fe}, \mathrm{Mn}$, and $\mathrm{Cu}$. The loss of $\mathrm{SOM}$, decrease of soil fine particles, and increase of soil $\mathrm{pH}$ were the main driving factors for the decrease of base cations and micronutrient availability as affected by soil coarseness. Unchanged concentrations of exchangeable $\mathrm{Ca}, \mathrm{K}$, and $\mathrm{Na}$ along the soil depth might result from the balance between plant cycling and leaching effects. The dominant role of plant cycling over leaching shaped the shallower distribution of exchangeable $\mathrm{Mg}$ as well as available $\mathrm{Fe}, \mathrm{Mn}$, and $\mathrm{Zn}$. The reduction and re-distribution of soil base cations and available micronutrients would potentially influence soil fertility and plant productivity in this desertified grassland ecosystem.

\section{The Supplement related to this article is available online at doi:10.5194/se-7-549-2016-supplement.}

Author contributions. Zhengwen Wang, Guoqing Yu, and Xingguo Han designed the experiments; Linyou Lü and Yan Zhao carried them out. Heyong Liu and Jinfei Yin helped with the laboratory analysis. Linyou Lü and Ruzhen Wang prepared the manuscript with contributions from all authors. Yong Jiang helped to revise the manuscript. Jiangtao Xiao created the figure of our experimental location.

Acknowledgements. This work was financially supported by the National Natural Science Foundation of China (41371251). 
Edited by: A. Jordán

\section{References}

Alamusa, Niu, C., and Zong Q.: Temporal and spatial changes of freeze-thaw cycles in Ulan'aodu Region of Horqin Sandy Land, Northern China in a changing climate, Soil Sci. Soc. Am. J., 78, 89-96, 2014.

Allington, G. and Valone, T.: Reversal of desertification: the role of physical and chemical soil properties, J. Arid Environ., 74, 973977, 2010

Antisari, L. V., Carbone, S., Gatti, A., Vianello, G., and Nannipieri, P.: Toxicity of metal oxide $\left(\mathrm{CeO}_{2}, \mathrm{Fe}_{3} \mathrm{O}_{4}, \mathrm{SnO}_{2}\right)$ engineered nanoparticles on soil microbial biomass and their distribution in soil, Soil Biol. Biochem., 60, 87-94, 2013.

Barthold, F. K., Wiesmeier, M., Breuer, L., Frede, H.-G., Wu, J., and Blank, F. B.: Land use and climate control the spatial distribution of soil types in the grasslands of Inner Mongolia, J. Arid Environ., 88, 194-205, 2013.

Beldin, S. I., Caldwell, B. A., Sollins, P., Sulzman, E. W., Lajtha, K., and Crow, S. E.: Cation exchange capacity of density fractions from paired conifer/grassland soils, Biol. Fert. Soils, 43, 837841, 2007.

Beyene, F.: Incentives and Challenges in Community - Based Rangeland Management: Evidence from Eastern Ethiopia, Land Degrad. Dev., 26, 502-509, 2015.

Bisaro, A., Kirk, M., Zdruli, P., and Zimmermann, W.: Global drivers setting desertification research priorities: insights from a stakeholder consultation forum, Land Degrad. Dev., 25, 5-16, 2014.

Burke, I. C., Lauenroth, W. K., Riggle, R., Brannen, P., Madigan, B., and Beard, S.: Spatial variability of soil properties in the shortgrass steppe: the relative importance of topography, grazing, microsite, and plant species in controlling spatial patterns, Ecosystems, 2, 422-438, 1999.

Cao, C., Jiang, D., Teng, X., Jiang, Y., Liang, W., and Cui, Z.: Soil chemical and microbiological properties along a chronosequence of Caragana microphylla Lam. plantations in the Horqin sandy land of Northeast China, Appl. Soil Ecol., 40, 78-85, 2008.

Cerdà, A., Gallart, F., Li, J., Papanastasis, V. P., Parmenter, R. R., Turnbull, L., Parsons, A. J., and Wainwright, J.: Long-range ecogeomorphic processes, in: Self-organized ecogeomorphic systems: confronting models with data for land-degradation in drylands, edited by: Müller, E. N., Wainwright, J., Parsons, A. J., and Turnbull, L., Springer, Dordrecht, 103-139, 2014.

Cheng, L., Zhu, J., Chen, G., Zheng, X., Oh, N. H., Rufty, T., and $\mathrm{Hu}$, S.: Atmospheric $\mathrm{CO}_{2}$ enrichment facilitates cation release from soil, Ecol. Lett., 13, 284-291, 2010.

Chen, F., Zeng, D., Narain, S. A., and Chen, G.: Effects of soil moisture and soil depth on nitrogen mineralization process under Mongolian pine plantations in Zhanggutai sandy land, PR China, J. Forest. Res., 16, 101-104, 2005.

Chadwick, O. A. and Chorover, J.: The chemistry of pedogenic thresholds, Geoderma, 100, 321-353, 2001.

Conte, C. A.: The forest becomes desert: Forest use and environmental change in Tanzania's West Usambara mountains, Land Degrad. Dev., 10, 291-309, 1999.
Escadafal, R., Barbero-Sierra, C., Exbrayat, W., Marques, M. J., Akhtar-Schuster, M., El Haddadi, A., and Ruiz, M.: First appraisal of the current structure of research on land and soil degradation as evidenced by bibliometric analysis of publications on desertification, Land Degrad. Dev., 26, 413-422, 2015.

Goodall, D. W.: Some considerations in the use of point quadrats for the analysis of vegetation, Aust. J. Biol. Sci., 5, 1-41, 1952.

Huang, D., Wang, K., and Wu, W.: Dynamics of soil physical and chemical properties and vegetation succession characteristics during grassland desertification under sheep grazing in an agro-pastoral transition zone in Northern China, J. Arid Environ., 70, 120-136, 2007.

IUSS Working Group WRB: World Reference Base for Soil Resources 2014, International soil classification system for naming soils and creating legends for soil maps, World Soil Resources Reports No. 106. FAO, Rome, 2014.

Jobbágy, E. G. and Jackson, R. B.: The distribution of soil nutrients with depth: global patterns and the imprint of plants, Biogeochemistry, 53, 51-77, 2001.

Jobbágy, E. G. and Jackson, R. B.: The uplift of soil nutrients by plants: biogeochemical consequences across scales, Ecology, 85, 2380-2389, 2004.

Lawrence, G. B., David, M. B., and Shortle, W.C.: A new mechanism for calcium loss in forest-floor soils, Nature, 378, 162-165, 1995.

Li, F., Cook, S., Geballe, G. T., and Burch Jr., W. R.: Rainwater harvesting agriculture: an integrated system for water management on rainfed land in China's semiarid areas, AMBIO: A Journal of the Human Environment, 29, 477-483, 2000.

Li, F., Zhao, L., Zhang, H., Zhang, T., and Shirato, Y.: Wind erosion and airborne dust deposition in farmland during spring in the Horqin Sandy Land of eastern Inner Mongolia, China, Soil Till. Res., 75, 121-130, 2004.

Lindsay, W. L. and Norvell, W. A.: Development of a DTPA soil test for zinc, iron, manganese, and copper, Soil Sci. Soc. Am. J., 42, 421-428, 1978.

Lopez, M.: Wind erosion in agricultural soils: an example of limited supply of particles available for erosion, Catena, 33, 17-28, 1998.

Lu, X., Mao, Q., Gilliam, F. S., Luo, Y., and Mo, J: Nitrogen deposition contributes to soil acidification in tropical ecosystems, Glob. Change Biol., 20, 3790-3801, 2014.

Marques, M. J., Bienes, R., Cuadrado, J., Ruiz-Colmenero, M., Barbero-Sierra, C., and Velasco, A.: Analysing perceptions attitudes and responses of winegrowers about sustainable land management in central Spain, Land Degrad. Dev., 26, 458-467, 2015.

McLean, E. O.: Soil pH and lime requirement, in: Methods of soil analysis, Part 2, Chemical and microbiological properties, edited by: Page, A. L., Miller, R. H., and Keeney, D. R., American Society of Agronomy, Madison, WI, USA, 199-224, 1982.

Miao, L., Moore, J. C., Zeng, F., Lei, J., Ding, J., He, B., and Cui, $\mathrm{X}$.: Footprint of research in desertification management in China, Land Degrad. Dev., 26, 450-457, 2015.

Nowak, C., Downard, R., and White, E.: Potassium trends in red pine plantations at Pack Forest, New York, Soil Sci. Soc. Am. J., 55, 847-850, 1991.

Ochoa-Hueso, R., Bell, M. D., and Manrique, E.: Impacts of increased nitrogen deposition and altered precipitation regimes on 
soil fertility and functioning in semiarid Mediterranean shrublands, J. Arid Environ., 104, 106-115, 2014.

Oorts, K., Vanlauwe, B., and Merckx, R.: Cation exchange capacities of soil organic matter fractions in a Ferric Lixisol with different organic matter inputs, Agr. Ecosyst. Environ., 100, 161-171, 2003.

Sharma, B., Arora, H., Kumar, R., and Nayyar, V.: Relationships between soil characteristics and total and DTPA-extractable micronutrients in Inceptisols of Punjab, Commun. Soil Sci. Plan., 35, 799-818, 2004.

Stark, J. M.: Causes of soil nutrient heterogeneity at different scales. in: Exploitation of Environmental Heterogeneity by Plants: Ecophysiological Processes Above and Below Ground, edited by: Caldwell, M. M and Pearcy, R., J. Wiley \& Sons, NY, 255-284, 1994.

Su, Y., Li, Y., Cui, J., and Zhao, W.: Influences of continuous grazing and livestock exclusion on soil properties in a degraded sandy grassland, Inner Mongolia, northern China, Catena, 59, 267-278, 2005.

Su, Y., Zhao, H., Zhao, W., and Zhang, T.: Fractal features of soil particle size distribution and the implication for indicating desertification, Geoderma, 122, 43-49, 2004.

Torres, L., Abraham, E. M., Rubio, C., Barbero, C., and Ruiz, M.: Desertification research in Argentina, Land Degrad. Dev., 26, 433-440, 2015.

Trudgill, S. T.: Soil and vegetation systems, Oxford University Press, NY, USA, 1988.

Van der Ploeg, M. J., Appels, W. M., Cirkel, D. G., Oosterwoud, M.R., Witte, J.-P. M., and Van der Zee, S. E. A. T. M.: Microtopography as a driving mechanism for ecohydrological processes in shallow groundwater systems, Vadose Zone J., 11, No. 3, 2012.

Vieira, R. M. S. P., Tomasella, J., Alvalá, R. C. S., Sestini, M. F., Affonso, A. G., Rodriguez, D. A., Barbosa, A. A., Cunha, A. P. M. A., Valles, G. F., Crepani, E., de Oliveira, S. B. P., de Souza, M. S. B., Calil, P. M., de Carvalho, M. A., Valeriano, D. M., Campello, F. C. B., and Santana, M. O.: Identifying areas susceptible to desertification in the Brazilian northeast, Solid Earth, 6, 347-360, doi:10.5194/se-6-347-2015, 2015.
Wang, R., Dungait, J. A. J., Creamer, C. A., Cai, J., Li, B., Xu, Z., Zhang, Y., Ma, Y.,and Jiang, Y.: Carbon and nitrogen dynamics in soil aggregates under long-term nitrogen and water addition in a temperate steppe, Soil Sci. Soc. Am. J., 79, 527-535, 2015.

Wang, T., Xue, X., Zhou, L., and Guo, J.: Combating aeolian desertification in northern China, Land Degrad. Dev., 26, 118-132, 2015.

Weinzierl, T., Wehberg, J., Böhner, J., and Conrad, O.: Spatial Assessment of Land Degradation Risk for the Okavango River Catchment, Southern Africa, Land Degrad. Dev., 27, 281-294, 2016.

Xie, L. W., Zhong, J., Chen, F. F., Cao, F. X., Li, J. J., and Wu, L. C.: Evaluation of soil fertility in the succession of karst rocky desertification using principal component analysis, Solid Earth, 6, 515-524, doi:10.5194/se-6-515-2015, 2015.

Xu, Q., Wang, T., Cai, C., Li, Z., and Shi, Z.: Effects of soil conservation on soil properties of citrus orchards in the Three - Gorges Area, China, Land Degrad. Dev., 23, 34-42, 2012.

Yan, X. and Cai, Y.: Multi-scale anthropogenic driving forces of karst rocky desertification in Southwest China, Land Degrad. Dev., 26, 193-200, 2015.

Zhou, R., Li, Y., Zhao, H., and Drake, S.: Desertification effects on $\mathrm{C}$ and $\mathrm{N}$ content of sandy soils under grassland in Horqin, northern China, Geoderma, 145, 370-375, 2008.

Zhang, Y., Xu, Z., Jiang, D., and Jiang, Y.: Soil exchangeable base cations along a chronosequence of Caragana microphylla plantation in a semi-arid sandy land, China, J. Arid Land, 5, 42-50, 2013.

Zhao, H., Zhou, R., Zhang, T., and Zhao, X.: Effects of desertification on soil and crop growth properties in Horqin sandy cropland of Inner Mongolia, north China, Soil Till. Res., 87, 175-185, 2006. 